\title{
THE MAGNETIC RECORDING OF PHYSICOCHEMICAL CONDITIONS OF VOLCANIC ROCKS FORMATION
}

\author{
Novruzov Z.A. \\ Geology and Geophysics Institute, Azerbaijan National Academy of Sciences \\ 119, H.Javid Ave.,Baku, Azerbaijan, AZ1143: znovruz@yahoo.com
}

Keywords: volcanic rocks, rock magnetism, physicochemical conditions of rock formation
Summary. Using methods of rock magnetism, the paper considers the possibility of understanding the physicochemical processes of rocks formation. The case study is the volcanic rocks drilled by the superdeep Saatly well. Within the interval of 3540-8126 m the composition of volcanic rocks varied with depth from basalts, andesite-basalts to dacites and rhyodacites. In rocks, magnetic minerals (iron and titanium oxides, iron sulfides, iron hydroxides and others) are sensitive to the conditions of their formation and consequent existence. This sensitivity to the physicochemical conditions of formation (as well as to the conditions of consequent existence) is reflected by the composition and degree of crystallization of magnetic grains. As a result of the study of the magnetic properties of volcanogenic rocks it was revealed that metamorphism (realized at depths of 3540-7000 m and mainly 5500-7000 m) leads to the crystallization of secondary fine magnetite grains carrying chemical remanent magnetization. Despite the intensive development of metamorphism, the system remains thermodynamically "conserved" at depths of 3540-7000 $\mathrm{m}$. The processes of low-temperature metasomatism developing at depths of 7000-8126 m led to a decrease in the concentration of ferrimagnetic minerals in the rocks. Chemical residual magnetization becomes rarer and this occurs when oxidized magnetite is found. In some cases the generations of secondary hematite and pyrite were detected. Such change in the composition, concentration and characteristics of the natural magnetic state can occur in the thermodynamically "disclosed" system.

(C) 2020 Earth Science Division, Azerbaijan National Academy of Sciences. All rights reserved.

\section{Introduction}

The study of the magnetic properties of volcanogenic rocks allows addressing such issue as the knowledge of the physicochemical conditions of rock formation (Pecherskiy et al., 1975). Physicochemical conditions for the formation and consequent existence of magnetic minerals (iron and titanium oxides, iron sulfides, iron hydroxides and many others) of rocks are recorded in their magnetic memory. First reason for this is the variable valence of iron. All magnetic minerals containing variable amounts of $\mathrm{Fe}^{2+}$ and $\mathrm{Fe}^{3+}$, as well as minerals that contain only $\mathrm{Fe}^{3+}$, are included in this subgroup. At the same time both of them can be oxidized or reduced under the corresponding physicochemical conditions (Chukhrov et al., 1975). The second reason is the relative instability of solid solutions (titanomagnetites that were formed and stable in a significantly different thermodynamic regime) under the mode of occurrence of already formed rocks
(Lindsley, 1965). The history of the formation and consequent existence of volcanogenic rocks is written in the form of natural remanent magnetization. An analysis of the origin of natural remanent magnetization and the study of the composition of magnetic minerals, their associations, structural features by rock magnetism methods will thus make it possible to decipher the magnetic record of rock history.

\section{Geological setting and volcanogenic core samples of ultra deep Saatly well}

The super deep well is located near the city of Saatly $\left(\lambda=39.91^{\circ} \mathrm{N}, \phi=48.36^{\circ} \mathrm{E}\right)$, Azerbaijan (Fig. 1). The region of the well location (design depth of 15 $\mathrm{km}$ ) is spaced in the Kura basin placed between the Greater and the Lesser Caucasus (the large tectonic constructions). According to deep structure the Kura basin is subdivided into three depressions: upper Kura basin, middle Kura basin and lower Kura ba$\sin$. The super deep Saatly well is located within the middle Kura basin. According to geophysical data 
interpretation the crystalline basement (around the Saatly local gravitational maximum) possesses the block structure (where there are rocks of persilicic and basic composition at a depth of $8 \mathrm{~km}$ ). Around the Saatly local gravitational maximum the crustal structure controversy was formed in two views. According to the first view the Earth crust consists of granite and basalt layers. According to the second view the Earth crust is singlelayer and it is presented only by mafic rocks. At Saatly area the features of the Earth crust and the reduced thickness of a sedimentary cover formed a basis for drilling of the super deep well.

Object of our researches are the volcanics located in the depths interval of 3540-8126 m. According to research papers (Abdullayev, Salakhov, 1983; Abdullayev et al., 1984) the development of the lowtemperature metamorphism (depth of 3540-7000 m) has been noted in the volcanogenic rocks. But from depths of $7000 \mathrm{~m}$ and deeper the development of the low-temperature metasomatism is revealed. The quantities of the studied volcanic rocks were 49. Three duplicate with cubic form $(1 \mathrm{~cm})$ were sawn from each sample.

The 3540-3560 m depth interval is characterized by andesite-basalts. In the depth interval of 3560$4360 \mathrm{~m}$ the thickness of volcanic rocks contains basalts. Basalts contain the potassium-enriched and sodium-enriched alkalinity.
The 4360-4700 m depth interval contains andesite-basalts. At depths of 4700-4800 $\mathrm{m}$ there is thickness of dolerites. The 4800-4900 m depth interval contains andesite-basalts. At depths of 4900-5000 $\mathrm{m}$ there is thickness of basalts. The $5000-5150 \mathrm{~m}$ depth interval contains andesitebasalts. At depths of 5150-5250 m there is thickness of dolerite (gabbro-norite). The 5250-5500 m depth intervals contain basalts. At depths of 5500$5650 \mathrm{~m}$ there is thickness of andesite-basalts. The 5650-6150 m depth interval contains andesites. At depths of 6150-6300 $\mathrm{m}$ there is thickness of andesite-basalts. The depth interval of 6300-6500 m contains andesites. At depths of 6500-6700 m there is thickness of andesite-basalts. The 6700$6880 \mathrm{~m}$ depth interval contains andesites. At depths of $6880-7030 \mathrm{~m}$ there is thickness of dolerite. The 7030-7250 m depth interval contains dacites. At depths of 7250-7300 m there is thickness of rhyodacites. The 7300-7400 m depth interval contains dolerites. At depths of 7400-7500 m there is thickness of rhyodacites. The 7500-7800 $\mathrm{m}$ depth interval contains dacites. At depths of $7800-7900 \mathrm{~m}$ there is thickness of rhyodacites. The 7900-8100 m depth interval contains andesite-dacites. At depths of $8100-8110 \mathrm{~m}$ there is thickness of rhyolites. The $8110-8126 \mathrm{~m}$ depth interval contains dacites.

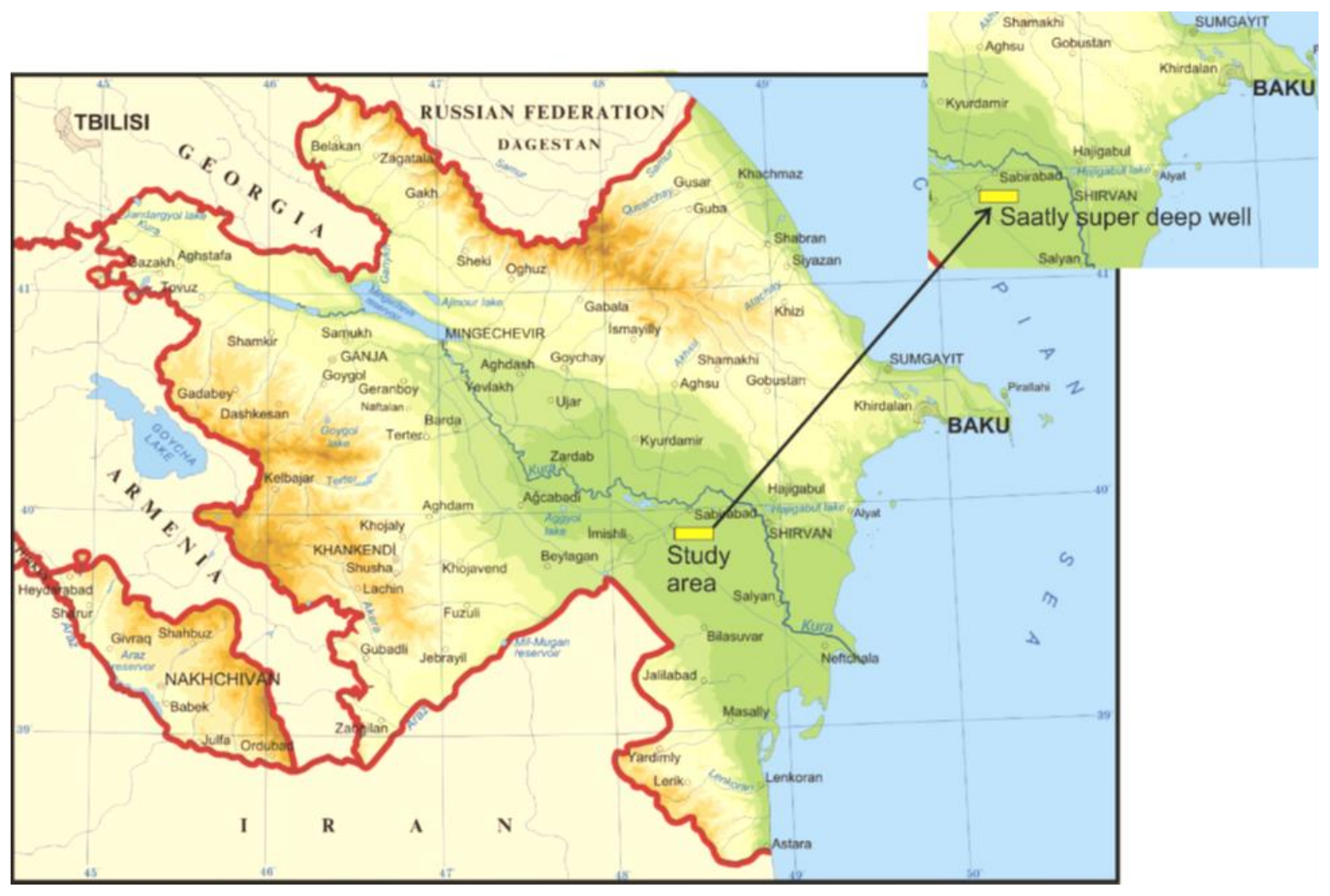

Fig.1. The Saatly super deep well location 
The studied column of volcanics changes thus with depth: from the mafics (andesite-basalts, basalts) to intermediate rocks (andesites) and then to persilic rocks (rhyodacites, dacites).

\section{Experimental procedures}

For carrying out magnetometric studies (volcanogenic rocks of ultra deep Saatly well) the following magnetic parameters were measured and calculated:

1) Saturation isothermal remanent (ferro- and ferrimagnetic substances behave paramagnetically) magnetization (SIRM or Mrs): the isothermal remanence acquired by a sample after it has been exposed to a saturating DC field.

2) Saturation magnetization (Ms): this measurement results from a hysteresis loop measurement and is the greatest magnetization acquired by a sample in the presence of the magnetic field causing it.

3) Curie temperature ( $\mathrm{Tc}-$ Curie point): The temperature above which ferro- and ferrimagnetic substances behave paramagnetically. Curie temperatures of the two most common palaeomagnetic carriers are $580^{\circ} \mathrm{C}$ for magnetite and $680^{\circ} \mathrm{C}$ for haematite. Above relaxation times the temperature $(\mathrm{Tb})$ is so short that the grain cannot hold a fixed magnetization direction on a laboratory timescale and it displays superparamagnetism. As the grain cools below this temperature ( $\mathrm{Tb})$, it exhibits stable behavior. This transition temperature is called the blocking temperature.

4) $\mathrm{Hc}$ - the coercivity of a sample that results from a hysteresis loop measurement. It is the field that is required to reduce the magnetization of a sample to 0 while the field is being applied;

$\mathrm{Hcr}$ - the coercivity of remanence of a sample that results from a hysteresis loop measurement. It is the field required to reduce the magnetization of a sample to 0 after the field has been turned off, i.e. the sample is measured in 0 fields;

$\mathrm{Hs}$ - saturation field of magnetization is the applied external magnetic field $\mathrm{H}$ when after further increasing of it the magnetization of the sample cannot increase;

5) Coefficient (factor) $\mathrm{Qn}=\mathrm{NRM} / \mathrm{kH}$ (where $\mathrm{NRM}$ - natural remanent magnetization; $\mathrm{k}$ - initial magnetic susceptibility, $\mathrm{H}$ - the constant magnetic field equal of $50 \mu \mathrm{T}$, and $\mathrm{kH}$ - inductive magnetization in the field of $\mathrm{H}$ ).

6) TRM (Jrt), thermal remanent magnetization or thermoremanent magnetization: The magnetization acquired by a ferromagnetic mineral grain during cooling of the grain through its Curie temperature or its blocking temperature.

7) ARM, anhysteretic remanent magnetization: A laboratory remanence that results from applying a small DC magnetic field (c. $50 \mu \mathrm{T}$ ) to a sample in the presence of an alternating magnetic field that is decreased from some peak value to 0 .

All laboratory measurements were carried out at the laboratory of the "Main Geomagnetic Field and Petromagnetism" of the Institute of Earth Physics of the Russian Academy of Sciences. The natural remanent magnetization (NRM), thermoremanent magnetization (TRM), anhysteretic remanent magnetization (ARM) and isothermal remanent magnetization (IRM) were measured on the magnetometer JR-4 (Brno, Czech Republic). Demagnetization and magnetic cleaning by alternating field (AF-cleaning) of samples were carried out at the semi-automatic device (RUV) in the 0-80 $\mathrm{A} / \mathrm{m}$ fields range.

\section{Petromagnetic analysis}

In the depth interval 3500-4300 $\mathrm{m}$ (Table) the Curie point ( $\mathrm{Tc}-$ magnetic transition temperature) varies between $510-585^{\circ} \mathrm{C}$, which indicates the presence of magnetite $\left(\mathrm{Tc}=585^{\circ} \mathrm{C}\right)$ or magnetite with a small titanium impurity $\left(\mathrm{Tc}=510 \div 575^{\circ} \mathrm{C}\right)$ in the studied rocks. As a result of thermomagnetic analysis it turned out that the detected ferrimagnets are stable to temperature influences. For the indicated depth range after the first heating of the sample to $600^{\circ} \mathrm{C}$ the $\mathrm{Ms}_{\mathrm{T}} / \mathrm{Ms}_{0}$ ratio (characterizing this stability to temperature influences) changes within $0.65 \div 1.00$ (on average about 0.8 ). The presence of soft magnetic ferromagnets is indirectly authenticated by $\mathrm{Bc}=(63.7 \div 238.7) \mathrm{mT}$ and $\mathrm{Bcr}=(10.3 \div 42.4) \mathrm{mT}$, confirming the results of thermomagnetic analysis.

In this depth interval MS changes significantly, reflecting the complex conditions of primary crystallization and high-temperature oxidation of the ferromagnetic fraction. A significant variation in the value of $M_{S}=(1158 \div 3557) \times 10^{-3} \mathrm{mAm}^{2} / \mathrm{kg}$ reflects a strong change of magnetite and titanomagnetite concentrations in the rock. The minimum value of $M_{s}=1158 \mathrm{mAm}^{2} / \mathrm{kg}$ corresponds to basalt, the maximum value of $\mathrm{M}_{\mathrm{s}}=3557 \mathrm{mAm}^{2} / \mathrm{kg}$ corresponds also to basalt.

In the rocks of the indicated depth interval the presence of thermo-stable magnetite (titanomagnetite) and a significant change in its concentration thus testify to the high-temperature oxidation of the primary ferrimagnetic fraction (titanomagnetite) and to different conditions of its crystallization. In the ferromagnetic fraction of the horizon's rocks any chemical changes did not occur.

Quite similar results were obtained for 4300$5000 \mathrm{~m}$ and 5000-6000 m depth intervals. As can be seen from Table, magnetite and magnetite with a low titanium impurity with $\mathrm{Tc}=550 \div 580^{\circ} \mathrm{C}$ were 
found in the indicated depth intervals. Only for individual horizons (for example, $4915 \mathrm{~m}$ and 5185 $\mathrm{m})$, the instability of the ferromagnetic fraction to first heating was noted $\left(\mathrm{Ms}_{\mathrm{T}} / \mathrm{Ms}_{0} \sim 0.5\right)$. Ferromagnets are generally stable to temperature effects and reflect the conditions of high-temperature oxidation. The presence of soft magnetic minerals is confirmed by the values $\mathrm{Bc}=(67.6 \div 238.7) \mathrm{mT}$ and $\mathrm{Bcr}=(9.7 \div 29.7) \mathrm{mT}($ Table $)$.

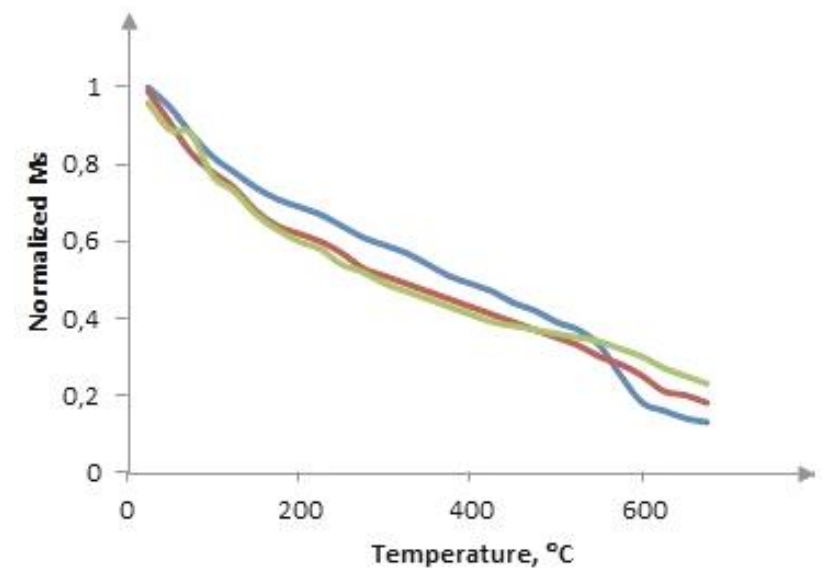

Fig. 2. Thermomagnetic $\mathrm{Ms} / \mathrm{Ms}_{0}$ curves of samples with the finely dispersed hematite (7-8 $\mathrm{km}$ depth interval)
For the studied volcanics from $6000-7000 \mathrm{~m}$ depths (Table) an exceptional constancy of the ferromagnetic fraction composition is observed (the presence of magnetite with $\mathrm{Tc}=580^{\circ} \mathrm{C}$ ). Only for andesites from the 6430-6435 $\mathrm{m}$ depth interval magnetite with a small content of titanium impurity with $\mathrm{Tc}=555-570^{\circ} \mathrm{C}$ is observed. The detected ferrimagnets exhibit, as a rule, high stability to heating $\left(\mathrm{Ms}_{\mathrm{T}} / \mathrm{Ms}_{0}=0.80 \div 1.00\right)$.

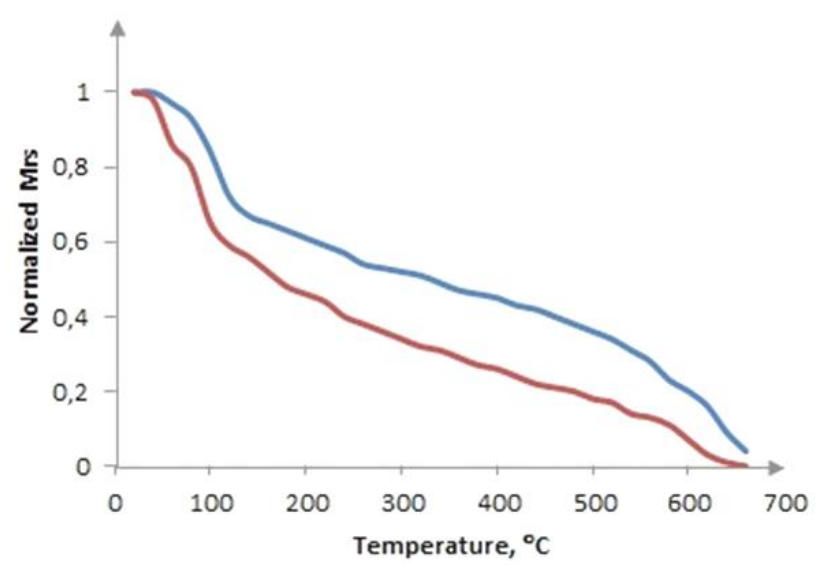

Fig. 3. Thermomagnetic Mrs/Mrso curves of samples with the finely dispersed hematite (7-8 km depth interval)

Magnetic characteristics of ultra deep Saatly well

Table

\begin{tabular}{|l|c|c|c|c|c|c|c|c|}
\hline \multicolumn{1}{|c|}{ Type of rock } & Depth, $\mathrm{m}$ & $\begin{array}{c}\mathrm{NRM}, \\
\mathrm{mA} / \mathrm{m}\end{array}$ & $\begin{array}{c}\mathrm{M}_{\mathrm{s}}, \mathrm{mAm}^{2} \\
\mathrm{~kg}^{-1}\end{array}$ & $\mathrm{Brs}, \mathrm{mT}$ & $\mathrm{Bcr}, \mathrm{mT}$ & $\mathrm{T}_{\mathrm{C}},{ }^{0} \mathrm{C}$ & $\mathrm{Ms}_{\mathrm{T}} / \mathrm{Ms}_{0}$ & $\mathrm{Mrs}_{\mathrm{T}} / \mathrm{Mrs}_{0}$ \\
\hline \multicolumn{1}{|c|}{1} & 2 & 3 & 4 & 5 & 6 & 7 & 8 & 9 \\
\hline Andesite-basalt & $3540-3600$ & 220 & 3557 & 238.7 & 14.3 & 530 & 0.87 & 1.28 \\
\hline Basalt & $3660-3666$ & 640 & 1158 & 159.2 & 42.4 & 585 & 0.66 & 0.89 \\
\hline Basalt & $3761-3767$ & 310 & 2631 & 238.7 & 20.0 & 575 & 1.00 & 0.82 \\
\hline Basalt & $3820-3825$ & 730 & 2462 & 159.2 & 20.7 & 575 & 0.84 & 1.64 \\
\hline Basalt & $3975-3981$ & 2590 & 2420 & 63.7 & 10.3 & 515 & 0.65 & 0.58 \\
\hline Basalt & $4062-4067$ & 1160 & 3347 & 119.4 & 21.0 & 515 & 0.71 & 2.15 \\
\hline Basalt & $4165-4171$ & 3380 & 1711 & 63.7 & 18.6 & 510 & 0.76 & 1.19 \\
\hline Basalt & $4250-4255$ & 1050 & 2203 & 119.4 & 25.6 & 540 & 0.89 & 1.18 \\
\hline Basalt & $4310-4315$ & 400 & 2822 & 159.2 & 9.7 & 580 & 0.85 & 1.63 \\
\hline Andesite-basalt & $4423-4428$ & 750 & 2377 & 199.0 & 23.8 & 580 & 0.87 & 1.49 \\
\hline Andesite-basalt & $4516-4522$ & 1780 & 3054 & 159.2 & 16.6 & 580 & 0.75 & 1.27 \\
\hline Andesite-basalt & $4600-4608$ & 1630 & 4394 & 159.2 & 21.8 & 580 & 1.00 & 1.30 \\
\hline Andesite-basalt & $4634-4640$ & 880 & 3052 & 199.0 & 19.6 & 570 & 0.85 & 1.46 \\
\hline Andesite-basalt & $4686-4692$ & 1240 & 3270 & 159.2 & 29.7 & 570 & 0.90 & 0.87 \\
\hline Dolerite & $4714-4719$ & 500 & 3493 & 119.4 & 21.0 & 580 & 0.80 & 0.68 \\
\hline Dolerite & $4770-4777$ & 1420 & 3932 & 159.2 & 17.4 & 580 & 1.00 & 1.38 \\
\hline Andesite-basalt & $4800-4807$ & 1010 & 2032 & 238.7 & 22.1 & 580 & 0.95 & 1.29 \\
\hline Andesite-basalt & $4881-4885$ & 970 & 3457 & 67.6 & 11.9 & 580 & 1.00 & 1.95 \\
\hline Basalt & $4915-4922$ & 1730 & 4975 & 119.4 & 15.0 & 550 & 0.50 & 1.60 \\
\hline Andesite & $5036-5040$ & 310 & 2188 & 159.2 & 16.2 & 550 & 0.85 & 0.67 \\
\hline Gabbro-norite & $5129-5132$ & 550 & 804 & 99.5 & 16.6 & 575 & 0.98 & 1.54 \\
\hline Basalt & $5185-5190$ & 560 & 2074 & 238.7 & 12.0 & 570 & 0.50 & 2.04 \\
\hline Basalt & $5270-5273$ & 3040 & 2437 & 238.7 & 18.5 & 570 & 0.88 & 1.30 \\
\hline Basalt & $5385-5390$ & 1830 & 3022 & 159.2 & 17.4 & 570 & 0.80 & 1.91 \\
\hline Basalt & $5467-5474$ & 590 & 2864 & 159.2 & 20.4 & 570 & 0.88 & 1.68 \\
\hline
\end{tabular}


Geology and geophysics

\begin{tabular}{|l|c|c|c|c|c|c|c|c|}
\hline \multicolumn{1}{|c|}{1} & 2 & 3 & 4 & 5 & 6 & 7 & 8 & 9 \\
\hline Andesite & $5544-5550$ & 1910 & 2638 & 119.4 & 19.9 & 570 & 0.90 & 1.32 \\
\hline Basalt & $5634-5636$ & 5540 & 3190 & 199.0 & 18.9 & 580 & 0.87 & 0.81 \\
\hline Andesite-basalt & $5746-5750$ & 3430 & 3052 & 119.4 & 20.6 & 580 & 1.00 & 1.13 \\
\hline Andesite & $5828-5830$ & 5900 & 3531 & 99.5 & 19.0 & 580 & 1.00 & 1.06 \\
\hline Andesite & $6000-6003$ & 1490 & 2575 & 99.5 & 16.0 & 580 & 0.90 & 1.02 \\
\hline Andesite & $6174-6178$ & 610 & 1502 & 79.6 & 9.9 & 580 & 0.90 & 2.85 \\
\hline Andesite-basalt & $6290-6295$ & 670 & 1424 & 119.4 & 12.3 & 580 & 0.90 & 1.38 \\
\hline Andesite & $6430-6435$ & 1000 & 189 & 159.2 & 14.4 & 555 & 0.80 & 1.67 \\
\hline Andesite & $6581-6583$ & 1820 & 3283 & 159.2 & 19.9 & 580 & 0.86 & 1.30 \\
\hline Andesite-basalt & $6740-6745$ & 470 & 262 & 119.4 & 13.2 & 580 & 0.90 & 1.76 \\
\hline Andesite & $6877-6882$ & 230 & 376 & 79.6 & 11.2 & 570 & 1.00 & 1.79 \\
\hline Dolerite & $6994-7003$ & 270 & 193 & 79.5 & 9.0 & 580 & 0.90 & 1.30 \\
\hline Dacite & $7038-7048$ & 10 & 45 & 119.4 & 21.0 & 600 & 0.89 & 2.40 \\
\hline Dacite & $7172-7176$ & 50 & 123 & 79.6 & 11.8 & 580 & 0.59 & 1.56 \\
\hline Rhyodacite & $7264-7276$ & 20 & 55 & 119.4 & 28.5 & 600 & 1.87 & 1.75 \\
\hline Dolerite & $7332-7343$ & 230 & 765 & 99.5 & 15.1 & 585 & 0.97 & 2.29 \\
\hline Rhyodacite & $7420-7428$ & 10 & 27 & 71.6 & 21.1 & 600 & 18.89 & 0.98 \\
\hline Dacite & $7576-7578$ & 300 & 374 & 79.6 & 14.3 & 600 & 0.94 & 1.17 \\
\hline Dacite & $7642-7646$ & 10 & 26 & 99.5 & 27.7 & 600 & 1.44 & 2.52 \\
\hline Dacite & $7729-7738$ & 550 & 436 & 79.6 & 11.9 & 600 & 0.93 & 1.01 \\
\hline Rhyodacite & $7874-7878$ & 410 & 2522 & 119.4 & 13.6 & 590 & 0.96 & 1.23 \\
\hline Andesite - dacite & $7991-7993$ & 330 & 626 & 55.7 & 12.7 & 600 & 0.95 & 1.32 \\
\hline Rhyolite & $8103-8108$ & 20 & 18 & 238.7 & 13.1 & 580 & - & 2.00 \\
\hline Dacite & $8108-8126$ & 4660 & 4164 & 99.4 & 22.1 & 580 & 0.94 & 0.90 \\
\hline
\end{tabular}

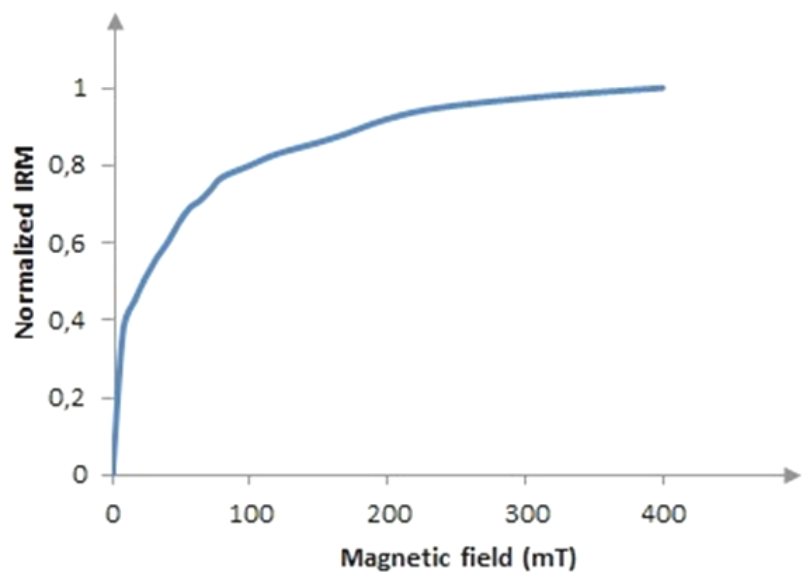

Fig. 4. IRM acquisition of samples with the finely dispersed hematite (7-8 km depth interval)

For the deepest (7000-8126 m) part of the column of volcanic rocks drilled by the Saatly well, along with magnetite and magnetite with a low Ti impurity content, the oxidized magnetite, hematite (secondary formations) and pyrite were noted in the rocks.

In samples where the presence of pyrite is not observed, magnetic minerals are relatively stable to heating up to $600-650^{\circ} \mathrm{C}$. The ratios $\mathrm{Ms}_{\mathrm{T}} / \mathrm{Ms}_{0}=0.59 \div 1.87$, $\mathrm{Mrs}_{\mathrm{T}} / \mathrm{Mrs}_{0}=0.90 \div 2.40$ indicate probably the partial oxidation of large magnetite (or magnetite with a low Ti impurity content) grains, which are present everywhere in rocks from the indicated depth interval.

At the same time pyrite (paramagnetic at above room temperature (Nagata, 1961) does not become apparent on the thermomagnetic curves and in the IRM acquisition parameters. Being unstable to heating in an oxidizing medium (Nagata, 1961) pyrite is however oxidized to highly magnetic compounds (Brodskaya, 1976) and can cause a significant increase in Ms and Mrs after heating. Such a "spike" of Ms and Mrs was noted for the horizon of 7420-7428 m (rhyodacite, Table 1) after heating the samples to $650^{\circ} \mathrm{C}$.

\section{Discussion and conclusions}

In the Saatly well volcanics the most important changes of the mineral magnetic properties in response to condition of formation and further "life" of rocks are in the magnetic properties of composition due to differences in magnetic mineralogy and in the grain size distribution concentration of the magnetic particles.

In rocks with the presence of finely dispersed hematite the Ms (T) curves (Fig. 4) become concave, which may argue the manifestation of the blocking temperature' spectrum of finely dispersed hematite grains (Avilova et al., 1978). This assumption is confirmed by the fact that $\mathrm{T}=600-625^{\circ} \mathrm{C}$ is significantly less than Tc of coarse-grained hematite $\left(675^{\circ} \mathrm{C}\right)$ (Nagata, 1961). Similar blocking temperatures (Tb) have also been registered by the SIRM versus temperature curves (typical curves are shown in Fig. 2).

In case of finely dispersed hematite presence in the rocks the parameters of isothermal magnetization significantly change (Fig. 3) (see Table). In fields above $397.77 \mathrm{mT}$ saturation remanence (SIRM) is reached while $\mathrm{Hc}$ increases to $137.07 \mathrm{mT}$. 
The magnetic parameters of the IRM's acquisition of magnetite $[\mathrm{Bc}=(55.77-238.74) \mathrm{mT}$, Hcr= (11.14-28.48) mT, see Table] (or magnetite with a low Ti impurity content) do not differ significantly from those of oxidized magnetite (Kudryavtseva, 1984). According to thermomagnetic studies $\mathrm{Tc}$ (and $\mathrm{Tb}$ ) for oxidized magnetite are shifted toward however higher temperatures compared to $\mathrm{Tc}$ (and $\mathrm{Tb}$ ) of stoichiometric magnetite $\left(580^{\circ} \mathrm{C}\right)$ and equal to about $600^{\circ} \mathrm{C}$.

Microprobe analysis (Novruzov, Tselmovich, 2018) of the ore fraction of volcanic rocks drilled by the superdeep Saatly well revealed mineral grains corresponding to primary crystallization. Homogeneous grains with the decomposition structure of titanomagnetite grains with a low $\mathrm{Ti}$ content were isolated. In this case decomposition structures are characteristic of high-temperature heterophase oxidation. By means of rock magnetism, in analyzing the composition (Novruzov, 2018) of magnetic minerals titanomagnetites with a low $\mathrm{Ti}$ content were found as the main ore fraction. Also when analyzing the origin of NRM it was revealed that the component of the thermoremanent magnetization is present in almost all the studied samples (Novruzov, 2018).

Microprobe analysis (Novruzov, Tselmovich, 2018) of the ore fraction showed also that correctly faceted grains of practically stoichiometric magnetite exist in the rocks. This magnetite could crystallize only due to secondary processes of low-temperature metamorphism under the conditions of a thermodynamically "closed" system. The single-domain (or

\section{REFERENCES}

Abdullayev R.N., Salakhov A.S. Comparative characteristic of the Jurassic volcanics of the Kurdamir-Saatly buried uplift and the northeastern part of the Lesser Caucasus. Proceedings of Academy of Sciences of Azerbaijan SSR. The Sciences of Earth, No. 4, 1983, pp. 14-23 (in Russian).

Abdullayev R.N., Salayeva F.O., Salakhov A.S. Magmatic complexes of the Middle Kura depression. In: Problems of mineralogy and lithology. Proceedings of AzNEFTECHIM, Baku, 1984, pp. 85-90 (in Russian).

Avilova T.E., Bagin V.I., Gendler T.S. About the difference of the properties of the thermoremanent and isothermal residual magnetizations of finely-dispersed hematites. Proceedings of Academy of Sciences of the USSR. The Physics of the Earth, No. 12, 1978, pp. 95-104 (in Russian).

Brodskaya S.Yu., Kuzmicheva E.V., Kuzmicheva T.P. et al. Magnetic properties of pyrrhotines and formation conditions of the Kholodninskoye deposit. Proceedings of Academy of Sciences of the USSR. The Physics of the Earth, No. 6, 1976, pp. 67-75 (in Russian).

Chukhrov F.V., Yermilova L.P., Gorshkov A.I. et al. Experimental data on the formation conditions of iron oxides. In: Hypergenic iron oxides. Nauka. Moscow, 1975, pp. 11-33 (in Russian).

Kudryavtseva G.P. Composition-structure and magnetic properties of natural ferrite oxides. Abstract of doctoral dissertation, Moscow, 1984, 44 p. (in Russian).

Lindsley D.H. Iron-titanium oxides. Carnegie Inst. Wash. Year Book, V. 64, 1965, pp. 87-97. pseudo-domain) structure of magnetic grains was discovered by means of rock magnetism when analyzing the composition (Novruzov, 2019a) and magnetic domain structure (Novruzov, 2019c). The fine stoichiometric magnetite grains were identified by analyzing the origin of the natural remanent magnetization. In the samples with the small magnetite grains the chemical remanent magnetization (CRM) (Novruzov, 2019b) is fixed. These are correctly faceted grainsare secondary stoichiometric magnetites (as result of low-temperature metamorphism processes under the thermodynamically "closed" conditions).

\section{Resume}

Based on magnetic studies of the volcanic rocks drilled by the Saatly well, the widespread distribution of magnetite and magnetite with a low Ti impurity was thus found in them. The presence of oxidized magnetite, hematite and pyrite is noted only in the deepest part of the volcanic rocks of well column. There can be argued that: a) processes of low-temperature metamorphism, intensively developing at depths above $5500 \mathrm{~m}$, do not lead to an increase in the partial pressure of oxygen in the system, and the system itself remains "closed" up to depths of $7000 \mathrm{~m}$; b) at depths of more than $7000 \mathrm{~m}$ secondary formations of the Fe group minerals indicate the variability of the redox environment in the system. This is evidence of development of low-temperature metasomatism. In 7000-8126 m depth intervals the system becomes a thermodynamically "open".

\section{ЛИТЕРАТУРА}

Lindsley D.H. Iron-titanium oxides. Carnegie Inst. Wash. Year Book, V. 64, 1965, pp. 87-97.

Nagata T. Rock Magnetism. Maruzen. Tokyo, 1961, 350 p.

Novruzov Z.A., Tselmovich V.A. Microroentgen spectral ore mineral analysis of Saatly well column volcanics. Stratigraphy and Sedimentology of Oil-Gas Basins (İnternational scientific journal), Baku, No. 2, 2018, pp. 70-84.

Novruzov Z.A. Research of magnetic properties of magnetic minerals of Saatly Well's section (depth of 3540-8126 m) for determination of natural remanent magnetization genesis. Azerbayjanda Geofizika Yenilikleri, Baku, No. 2, 2018, pp. 41-46.

Novruzov Z.A. Composition of magnetic minerals of volcanogenic rocks according to petromagnetic data. Azerbayjanda GeofizikaYenilikleri, Baku, No. 1, 2019a, pp.16-21.

Novruzov Z.A. New approach in identification of chemical magnetization in the volcanics by means of rock magnetism. Azerbayjanda Geofizika Yenilikleri, Baku, No. 2, 2019b, pp. 16-21.

Novruzov Z.A. Domain structure of volcanics' ferromagnetic grains: A case study of the Saatly ultra deep well, Azerbaijan. Geophysical Journal, Kiev, No. 3, 2019c, pp. 203-210.

Абдуллаев Р.Н., Салахов А.С. Сравнительная характеристика юрских вулканитов Кюрдамир-Саатлинского погребенного поднятия и северо-восточной части Малого Кавказа. Изв. АН АзССР. Науки о Земле, 1983, No. 4, c. 14-23. 
Nagata T. Rock Magnetism. Maruzen. Tokyo, 1961, 350 p.

Novruzov Z.A., Tselmovich V.A. Microroentgen spectral ore mineral analysis of Saatly well column volcanics. Stratigraphy and Sedimentology of Oil-Gas Basins (İnternational scientific journal), Baku, No. 2, 2018, pp. 70-84.

Novruzov Z.A. Research of magnetic properties of magnetic minerals of Saatly Well's section (depth of 3540-8126 m) for determination of natural remanent magnetization genesis. Azerbayjanda Geofizika Yenilikleri, Baku, No. 2, 2018, pp. 41-46.

Novruzov Z.A. Composition of magnetic minerals of volcanogenic rocks according to petromagnetic data. Azerbayjanda GeofizikaYenilikleri, Baku, No.1, 2019a, pp. 16-21.

Novruzov Z.A. New approach in identification of chemical magnetization in the volcanics by means of rock magnetism. Azerbayjanda Geofizika Yenilikleri, Baku, No. 2, 2019b, pp. 16-21.

Novruzov Z.A. Domain structure of volcanics' ferromagnetic grains: A case study of the Saatly ultra deep well, Azerbaijan. Geophysical Journal, Kiev, No. 3, 2019c, pp. 203-210.

Pecherskiy D.M., Bagin V.I., Brodskaya S.Yu., Sharonova Z.V. Magnetism and formation conditions of igneous rocks. Nauka. Moscow, 1975, 288 p. (in Russian).
Абдуллаев Р.Н., Салаева Ф.О., Салахов А.С. Магматические комплексы Среднекуринской впадины. В сб.: Вопросы минералогии и литологии. Баку, Тр. АзНЕФТЕХИМа им. М.Азизбекова, 1984, с. 85-90.

Авилова Т.Е., Багин В.И., Гендлер Т.С. О различии свойств термоостаточной и нормальной остаточной намагниченностей тонкодисперсных гематитов. Изв. АН СССР, сер. Физика Земли, №. 12, 1978, с. 95-104.

Бродская С.Ю., Кузьмичева Е.В., Кузьмичева Т.П. и др. Магнитные свойства пирротинов и условия формирования Холоднинского месторождения. Изв. АН СССР, сер. Физика Земли, №. 6, 1976, с. 67-75.

Кудрявцева Г.П. Состав-структура и магнитные свойства природных ферритов-окислов. Автореферат докторской диссертации. Москва, 1984, 44 с.

Печерский Д.М., Багин В.И., Бродская С.Ю., Шаронова З.В. Магнетизм и условия образования изверженных горных пород. Наука. Москва, 1975, 288 с.

Чухров Ф.В., Ермилова Л.П., Горшков А.И. и др. Экспериментальные данные об условиях образования окислов железа. В кн.: Гипергенные окислы железа. Наука. Москва, 1975, с. 11- 33.

\title{
МАГНИТНАЯ ЗАПИСЬ ФИЗИКО-ХИМИЧЕСКИХ УСЛОВИЙ ФОРМИРОВАНИЯ ВУЛКАНИЧЕСКИХ ПОРОД
}

\author{
Новрузов 3.А. \\ Институт геологии и геофизики НАНА \\ AZ1143, Азербайджан, г.Баку, просп.Г.Джавида, 119: zпоvruz@yahoo.com
}

Резюме. В статье рассматривается возможность понимания физико-химических процессов образования горных пород, используя методы магнетизма горных пород. Объектом исследования являются вулканические породы, пробуренные сверхглубокой Саатлинской скважиной. В интервале 3540-8126 м с глубиной состав вулканических пород изменялся от базальтов, андезито-базальтов до дацитов и риодацитов. В породах магнитные минералы (оксиды железа и титана, сульфиды железа, гидроксиды железа и др.) чувствительны к условиям их образования и последующего существования. Эта чувствительность к физико-химическим условиям образования (а также к условиям последующего существования) отражается в составе и степени окристаллизованности магнитных зерен.

В результате изучения магнитных свойств вулканогенных пород было выявлено, что метаморфизм (реализуемый на глубинах 3540-7000 м, в основном 5500-7000 м) приводит к кристаллизации вторичных мелкозернистых зерен магнетита, несущих химическую остаточную намагниченность. Несмотря на интенсивное развитие метаморфизма, система остается термодинамически «закрытой» на глубинах 3540-7000 м.

Процессы низкотемпературного метасоматоза, развивающиеся на глубинах 7000-8126 м, привели к снижению концентрации ферримагнитных минералов в породах. Химическая остаточная намагниченность становится более редкой, и это реализуется при наличии окисленного магнетита. В некоторых случаях были обнаружены генерации вторичных гематита и пирита. Такое изменение состава, концентрации и характеристик естественного магнитного состояния может происходить в термодинамически «открытой» системе.

Ключевые слова: вулканические породы, магнетизм горных пород, физико-химические условия формирования пород

\section{VULKANIK SÜXURLARIN FİZIKİ-KIMMYəVİ əMӘLӘGəLMə ŞəRAITINIIN MAQNIT QEYDLəRİ}

\author{
Novruzov Z.A. \\ AMEA Geologiya va Geofizika İnstitutu \\ AZ1143, Azarbaycan, Bakı şəh., H.Cavid prosp.,119: znovruz@yahoo.com
}

\begin{abstract}
Xülasə. Məqalədə süxurların maqnetizmi metodlarından istifadə edərək onlaların fiziki-kimyəvi əmələgəlmə proseslərinin dərkedilmə imkanı nəzərdən keçirilir. Tədqiqat obyekti ifratdərin Saatlı quyusu ilə qazılmış vulkanik süxurlardır. $3540-8126 \mathrm{~m}$ dərinlik intervalında vulkanogen süxurlarının tərkibi bazalt, andezibazaltlardan dasit və riodasitlərə qədər dəyişilmişdir. Süxurlarda maqnit mineralları (dəmir və titan oksidləri, dəmir sulfidləri, dəmir hidroksidləri və s.) özünün əmələgəlmə və sonraki mövcudluğu şəraitinə həssasdır. Fiziki-kimyəvi əmələgəlmə şəraitinə (habelə sonrak1 mövcudluq şəraitinə) olan bu həssaslıq maqnit zərrəciklərin tərkibində və kristallaşma dərəcəsində əks olunur.

Vulkanogen süxurların maqnit xüsusiyyətlərinin öyrənilməsi nəticəsində aşkarlanmışdır ki, kimyəvi qalıq maqnitləşməni daşıyan törəmə xırda zərrəciklərin kristallaşmasına metamorfizm (3540-7000 m, əsasən də 5500-7000 m dərinliklərdə) səbəb olmuşdur. Metamorfizmin intensiv inkişafına baxmayaraq, sistem 3540-7000 m dərinliklərdə termodinamik "qapalı" olaraq qalır.

7000-8126 m dərinliklərdə inkişaf edən aşağı temperaturlu metasomatoz prosesləri süxurlarda ferrimaqnit mineralların konsentrasiyasının azalmasına səbəb olmuşdur. Kimyəvi qalıq maqnitləşmə azalmağa doğru gedir və bu da oksidləşmiş maqnetitin iştiraki bağlıdır. Bəzi hallarda törəmə hematit və piritin generasiyaları aşkar edilmişdir. Tərkibin belə dəyişməsi, təbii maqnit halının konsentrasiyası və xüsusiyyətləri termodinamik "açıq" bir sistemdə baş verə bilər.

Açar sözlor: vulkanik suxurlar, suxurların magnetizmi, suxurların əməla galməsinin fiziki-kimyəvi şəraiti
\end{abstract}

